\title{
Regional Heritability Mapping of Quantitative Trait Loci Controlling Traits Related to Growth and Productivity in Popcorn (Zea mays L.)
}

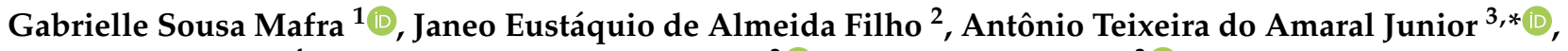 \\ Carlos Maldonado ${ }^{4}$, Samuel Henrique Kamphorst ${ }^{3}{ }^{(0)}$, Valter Jário de Lima ${ }^{3}{ }^{(D}$, Divino Rosa dos Santos Junior ${ }^{3}$, \\ Jhean Torres Leite ${ }^{3} \mathbb{D}$, Pedro Henrique Araujo Diniz Santos ${ }^{3} \mathbb{D}$, Talles de Oliveira Santos ${ }^{3} \mathbb{D}$, \\ Rosimeire Barboza Bispo ${ }^{3}$, Uéliton Alves de Oliveira ${ }^{3}$, Vitor Batista Pinto ${ }^{3}$, Alexandre Pio Viana ${ }^{3}$, \\ Caio Cezar Guedes Correa ${ }^{3}$, Sunny Ahmar ${ }^{5}\left(\mathbb{D}\right.$ and Freddy Mora-Poblete ${ }^{5}\left[{ }^{\circ}\right.$
}

check for updates

Citation: Mafra, G.S.; de Almeida Filho, J.E.; do Amaral Junior, A.T.; Maldonado, C.; Kamphorst, S.H.; de Lima, V.J.; dos Santos Junior, D.R.; Leite, J.T.; Santos, P.H.A.D.; de Oliveira Santos, T.; et al. Regional Heritability Mapping of Quantitative Trait Loci Controlling Traits Related to Growth and Productivity in Popcorn (Zea mays L.). Plants 2021, 10, 1845. https://doi.org/10.3390/ plants10091845

Academic Editor: Tika Adhikari

Received: 17 June 2021

Accepted: 31 August 2021

Published: 6 September 2021

Publisher's Note: MDPI stays neutral with regard to jurisdictional claims in published maps and institutional affiliations.

Copyright: (c) 2021 by the authors. Licensee MDPI, Basel, Switzerland. This article is an open access article distributed under the terms and conditions of the Creative Commons Attribution (CC BY) license (https:/ / creativecommons.org/licenses/by/ $4.0 /)$.
1 Centro de Ciências Agrárias, Universidade Estadual da Região Tocantina do Maranhão, R. Godofredo Viana, 1300, Imperatriz 65900-000, Brazil; gabrielle.smafra@yahoo.com.br

2 Bayer, Estrada da Invernadinha, 2000, Coxilha 99145-000, Brazil; janeo.filho@bayer.com

3 Laboratory of Plant Breeding, Center of Agricultural Science and Technology, Darcy Ribeiro State University of Northern Rio de Janeiro, Av. Alberto Lamego, 2000, Campos dos Goytacazes 28013-602, Brazil; samuelkampho@hotmail.com (S.H.K.); valter_jario@hotmail.com (V.J.d.L.); juniorifagro@gmail.com (D.R.d.S.J.); torresjhean@gmail.com (J.T.L.); phsantos2004@yahoo.com.br (P.H.A.D.S.); tallesdeoliveira@live.com (T.d.O.S.); rosimeirebarboza1@hotmail.com (R.B.B.); uelitonalves2011@hotmail.com (U.A.d.O.); vvitorbp@gmail.com (V.B.P.); pirapora@uenf.br (A.P.V.); caiocagronomo@gmail.com (C.C.G.C.)

4 Instituto de Ciencias Agroalimentarias, Animales y Ambientales, Universidad de O'Higgins, San Fernando 3070000, Chile; cmaldo1782@gmail.com

5 Institute of Biological Sciences, University of Talca, 1 Poniente 1141, Talca 3460000, Chile; sunnyahmar13@gmail.com (S.A.); morapoblete@gmail.com (F.M.-P.)

* Correspondence: amaraljr@uenf.br; Tel.: +55-22-999-220-192

Abstract: The method of regional heritability mapping (RHM) has become an important tool in the identification of quantitative trait loci (QTLs) controlling traits of interest in plants. Here, RHM was first applied in a breeding population of popcorn, to identify the QTLs and candidate genes involved in grain yield, plant height, kernel popping expansion, and first ear height, as well as determining the heritability of each significant genomic region. The study population consisted of $98 \mathrm{~S} 1 \mathrm{families}$ derived from the 9th recurrent selection cycle (C-9) of the open-pollinated variety UENF-14, which were genetically evaluated in two environments (ENV1 and ENV2). Seventeen and five genomic regions were mapped by the RHM method in ENV1 and ENV2, respectively. Subsequent genomewide analysis based on the reference genome B73 revealed associations with forty-six candidate genes within these genomic regions, some of them are considered to be biologically important due to the proteins that they encode. The results obtained by the RHM method have the potential to contribute to knowledge on the genetic architecture of the growth and yield traits of popcorn, which might be used for marker-assisted selection in breeding programs.

Keywords: candidate genes; linkage disequilibrium; genomic regions; regional heritability mapping; single nucleotide polymorphism

\section{Introduction}

Maize (Zea mays L.) is among the most important cereal crops in the world in addition to wheat and rice [1], which has been widely cultivated due to its nutritional composition, versatility, and broad adaptability. Both the land area used for maize grain production and the amount of maize produced per unit area in Brazil has increased in recent years by $25 \%$ and $60 \%$, respectively [2], which makes Brazil the third largest maize grain producer worldwide. Popcorn is a special type of maize primarily used for human consumption due 
to its exceptional nutritional and functional properties, i.e., the average dietary fiber content of $17.79 \%$, and low-calorie count when prepared without oil or fat [3]. The economically most important traits evaluated in popcorn breeding programs are grain yield (GY) and popping expansion (PE) [4]. However, the selection of cultivars based on traits such as plant height $(\mathrm{PH})$ and ear height $(\mathrm{EH})$ have important effects on plant lodging in intensive maize cultivation systems [1]. The yield (GY and PE) and growth (PH and EH) traits of maize are usually quantitatively inherited, and their genetic basis is controlled by the interaction between multiple genetic and environmental factors [1,5-7].

A successful tool to explain the genetic basis of complex traits in association studies, which allow the identification of quantitative trait loci (QTLs) based on the significant associations between genotypic markers and phenotypic data [8]. The identification of QTLs related to PE and GY has been reported in several studies, for example, simple sequence repeat (SSR) and single-nucleotide polymorphism (SNP) markers [5,8-12]. Thakur et al. [10] identified three QTLs associated (using SSR markers) with the popping volume, which covers $78 \%$ of total phenotypic variance. Dell'Acqua et al. [12] identified three suggestive QTLs for GY, of which the locus on the short arm of chromosome 6 was defined as a major QTL, accounting for 13\% of the variance in GY. The identification of QTLs related to PE has mainly been reported using SSR markers, presenting a reduced number of identified QTLs. This fact may be related to the low density of markers used. The use of high-throughput genotyping technologies has filled this gap, as they are more accurate and allow the deeper dissection of genomes of species such as popcorn [13].

The SNP has been widely used in association studies for the detection of a large number of QTLs and candidate genes involved in the yield and growth $[8,14,15]$. Despite their wide usage, association studies have been criticized, since according to certain studies, they are inefficient in detecting the total genetic variation of complex traits [16,17]. In this sense, some studies have reported that SNPs markers associated with a complex trait can typically capture only a small proportion of genetic variance [10], which has been called the "missing heritability" problem [18].

Research in human genetics has shown that multiple independent loci with different frequencies and allelic effects are commonly located in the same gene region or shortsegment regions $[19,20]$. These loci may be undetectable by single SNP analyses since this type of analysis is not sufficiently sensitive to identify relatively small individual allelic effects, even if the cumulative effect of the entire locus on the trait variance is high [17].

To overcome this drawback and capture most of the genetic variance that cannot be captured by association studies, recent studies have proposed a method called regional heritability mapping (RHM) [16,17], which facilitates the detection of the genetic variation related to each genome segment [16-18,21]. The RHM method uses a relationship matrix between individuals based on common and rare SNP information from small regions of genomes to estimate the trait variance explained by each region and localize variation [22]. In RHM, the genomic and regional heritability is estimated using a mixed model based on the restricted maximum likelihood (REML) and two components of variance; one is attributed to the entire genome and the other to a specific genomic region [17]. It is suggested here that an approach with the RHM methodology could identify common and rare variants involved in the expression of complex traits, e.g., of grain yield and popping expansion in popcorn populations.

To date, studies based on RHM analysis are not well consolidated for plant species, since most research using this type of methodology has been developed to identify QTLs related to complex traits in humans and animals $[17,22,23]$. Thus far, few studies with plant species are available in the literature. Some examples are the comparisons of the methodologies of association studies and RHM in Eucalyptus [18], in common bean (Phaseolus vulgaris L.) [24], and cassava (Manihot esculenta Crantz) [25]. Resende et al. [18] compared an association analysis and RHM in complex traits of Eucalyptus and observed that RHM allowed the identification of 13 more QTLs than association analysis. In addition, the authors observed that RHM outperformed the genome-wide association study analysis 
for all traits evaluated, capturing, in general, two or three times the amount of genomic heritability. Similarly, RHM allowed a greater proportion of genomic heritability to be explained compared to association analysis, in accessions of Phaseolus vulgaris L. [24].

To the best of our knowledge, this is the first study to apply RHM to understand the genetic basis of complex traits in popcorn. The objectives of this study were to identify genomic regions and candidate genes associated with growth (plant height and ear height), popping expansion, and grain yield of popcorn, as well as to examine the genomic heritability attributed to these traits, using regional heritability mapping with a mixed model approach.

\section{Results}

The average values for ear height $(\mathrm{EH})$, plant height $(\mathrm{PH})$, and grain yield (GY) differed between the two environments, with EH and PH higher values in ENV2 (36\% and 18\%, respectively) to ENV1, while GY in ENV1 was 20\% higher than ENV2 (Supplementary Table S1). On the other hand, PE did not show changes between ENV1 and ENV2 (28.7 and 27.8 , respectively). A histogram for the four traits and correlation coefficients between pairs of traits is shown in Figure 1. The normality hypothesis was significant in all traits in both environments. The coefficients of correlation among EH, GY, and PH were positive and statistically different from zero ( $p$-value $<0.001$ ) in ENV1 and ENV2, with values of $r=0.21$ and 0.26 for EH-GY (ENV1 and ENV2, respectively), $r=0.80$ and 0.76 in EH-PH (ENV1 and ENV2, respectively) and $r=0.24$ and 0.31 in PH-GY (ENV1 and ENV2, respectively).

A
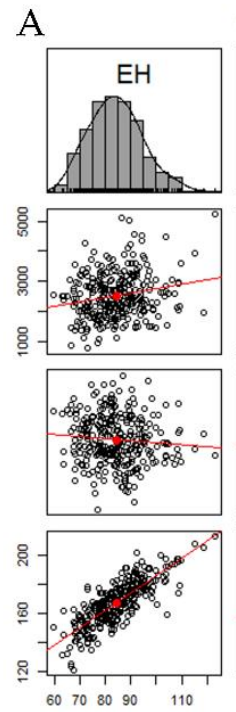
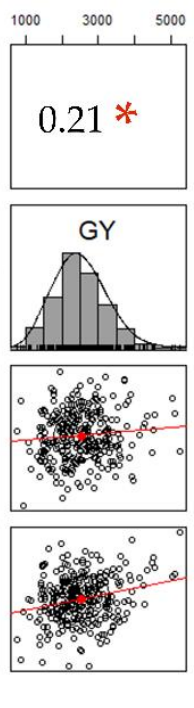

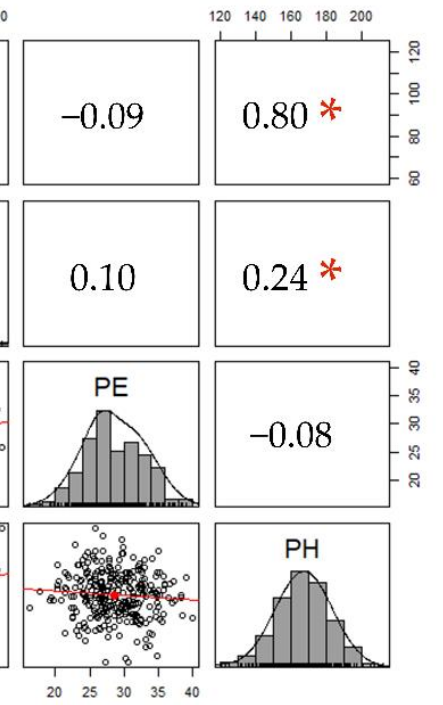

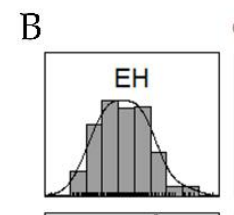
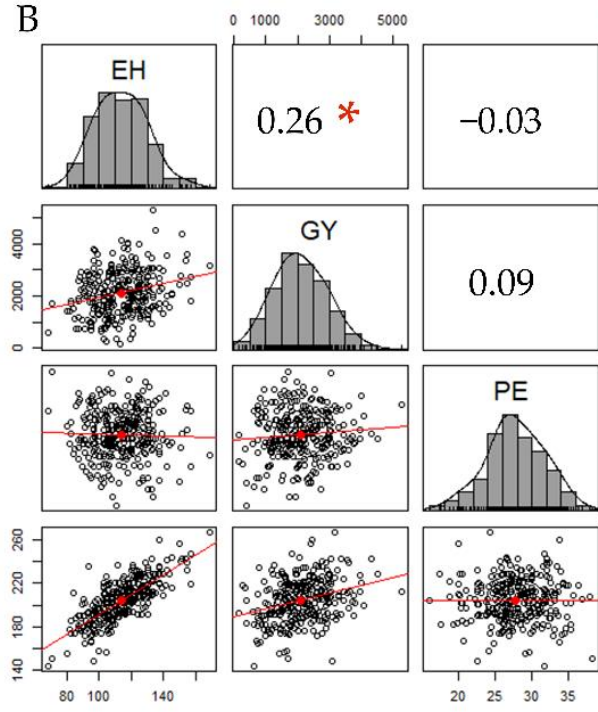

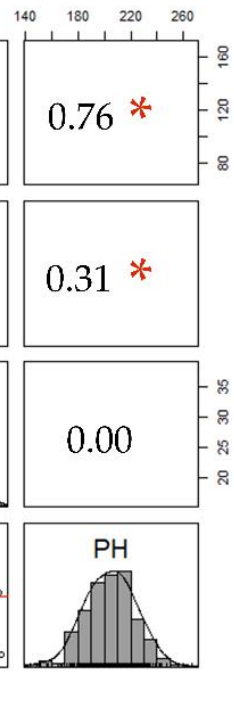

Figure 1. Plot representing phenotypic distribution and correlation for EH (ear height), GY (grain yield), PE (kernel popping expansion), and PH (plant height) traits, evaluated in (A) Campos dos Goytacazes (ENV1) and (B) Itaocara (ENV2). The diagonal line of the plot shows the histograms and the distribution of the observed phenotypes values. The lower off-diagonal is the scatterplot between the four traits, whereas the upper off-diagonal represents the correlation value between traits. Significant correlations $(p$-value $<0.001)$ are tagged with an asterisk.

\subsection{SNP Data, LD, and Detection of Associations via RHM}

21,442 polymorphic loci were identified among the maize plants from the breeding population throughout the Capture Seq method [26]. Individuals with a data loss of upper to $10 \%$ were removed resulting in 196 individuals. Subsequently, the SNPs were filtered to 10,507 by selecting the loci with MAF (Minor Allele Frequency) upper 0.05 and with less than $5 \%$ of missing data. The molecular markers were aligned with the 10 chromosomes of the reference genome of maize and presented a wide distribution throughout the genome. The average number of SNPs per chromosome was 1051, ranging from 778 on chromosome 6 to 1598 on chromosome 1 . 
The pattern of LD was estimated for each chromosome considering all SNPs belonging to the same chromosome. The slowest LD decay was observed in chromosome 8 , in which half of the decay occurred at $\sim 151 \mathrm{~Kb}$ (kilobase pairs), while chromosome 4 decreased the fastest, in which half of the decay was observed at $\sim 76 \mathrm{~Kb}$. The average half of the LD across the chromosomes was $\sim 110 \mathrm{~Kb} \pm 6.82$ (Figure 2). This result is consistent with that previously reported by [27], which observed that with the same population, half of the LD occurred in $\sim 107 \mathrm{~Kb}$.
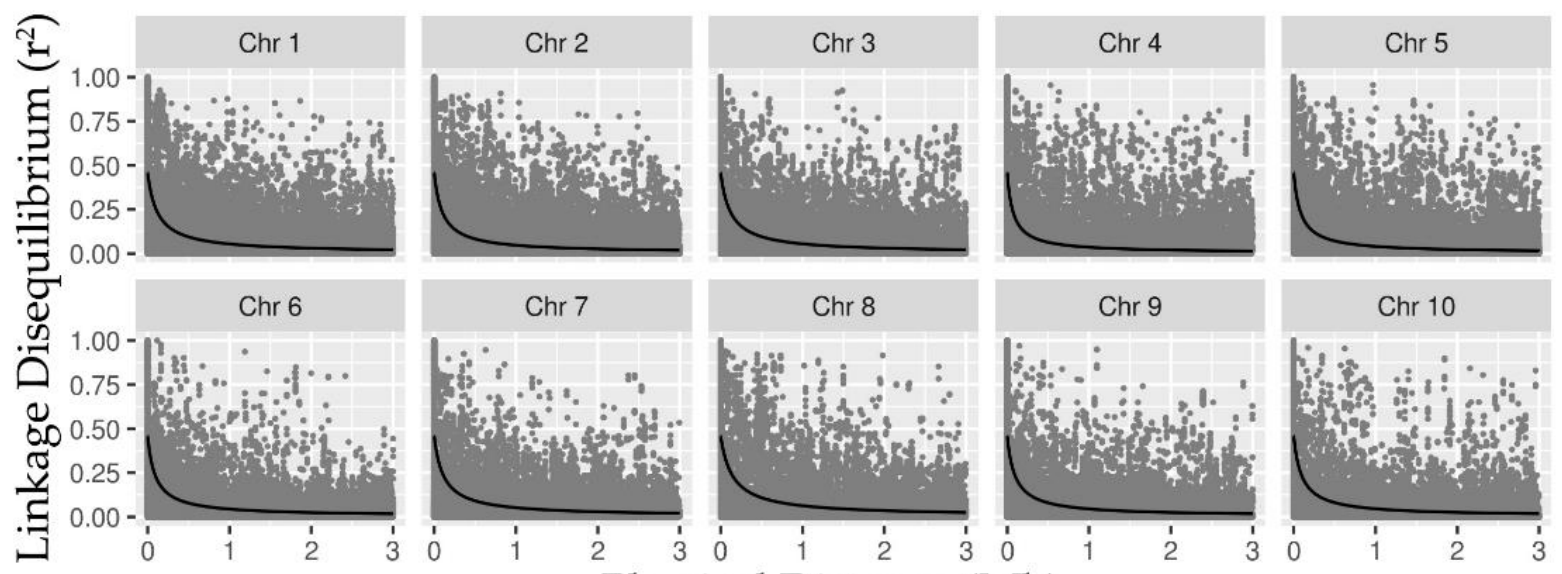

Physical Distance $(\mathrm{Mb})$

Figure 2. Decay of linkage disequilibrium (LD) of all SNPs (10.507) in the ten chromosomes estimated by $r^{2}$ (y-axis) along with physical distance in $\mathrm{Mb}$ (x-axis).

Seventeen QTLs were found by RHM in ENV1, each encompassing between 2 and 8 SNPs on chromosomes 1, 2, 4, 5, 6, and 8, while in ENV2, five QTLs were mapped, which ranged between 2 and 9 SNPs on chromosomes 2, 4 and 7 (Figures 3 and 4). In ENV1, the regional QTLs for EH and $\mathrm{PH}$ were located on individual chromosomes, while QTLs for GY and PE were mapped on several different chromosomes (Figure 3 and Supplementary Table S2). Notably, three regionals QTL (two associated with GY and one associated with PE) were detected at the same positions as the QTLs detected by Mafra et al. [8] using SNP-based mixed-model association (Supplementary Table S2). In ENV2 (Figure 4 and Supplementary Table S2), for trait GY, regional QTLs were identified on individual chromosomes, while for $\mathrm{EH}$, they were mapped on different chromosomes. Heritability varied between $0.079(\mathrm{EH})$ and $0.93(\mathrm{GY})$ in ENV1 and between $0.078(\mathrm{GY})$ and $0.14(\mathrm{EH})$ in ENV2. The genome-wide distribution of regional heritability QTLs mapped by RHM along the 10 maize chromosomes are shown in Figures 3 and 4, displaying significant QTLs $\left(p\right.$-value $\leq 0.001$, or $-\log _{10}(p$-value $\left.) \geq 3\right)$ found in ENV 1 and ENV 2, respectively. 

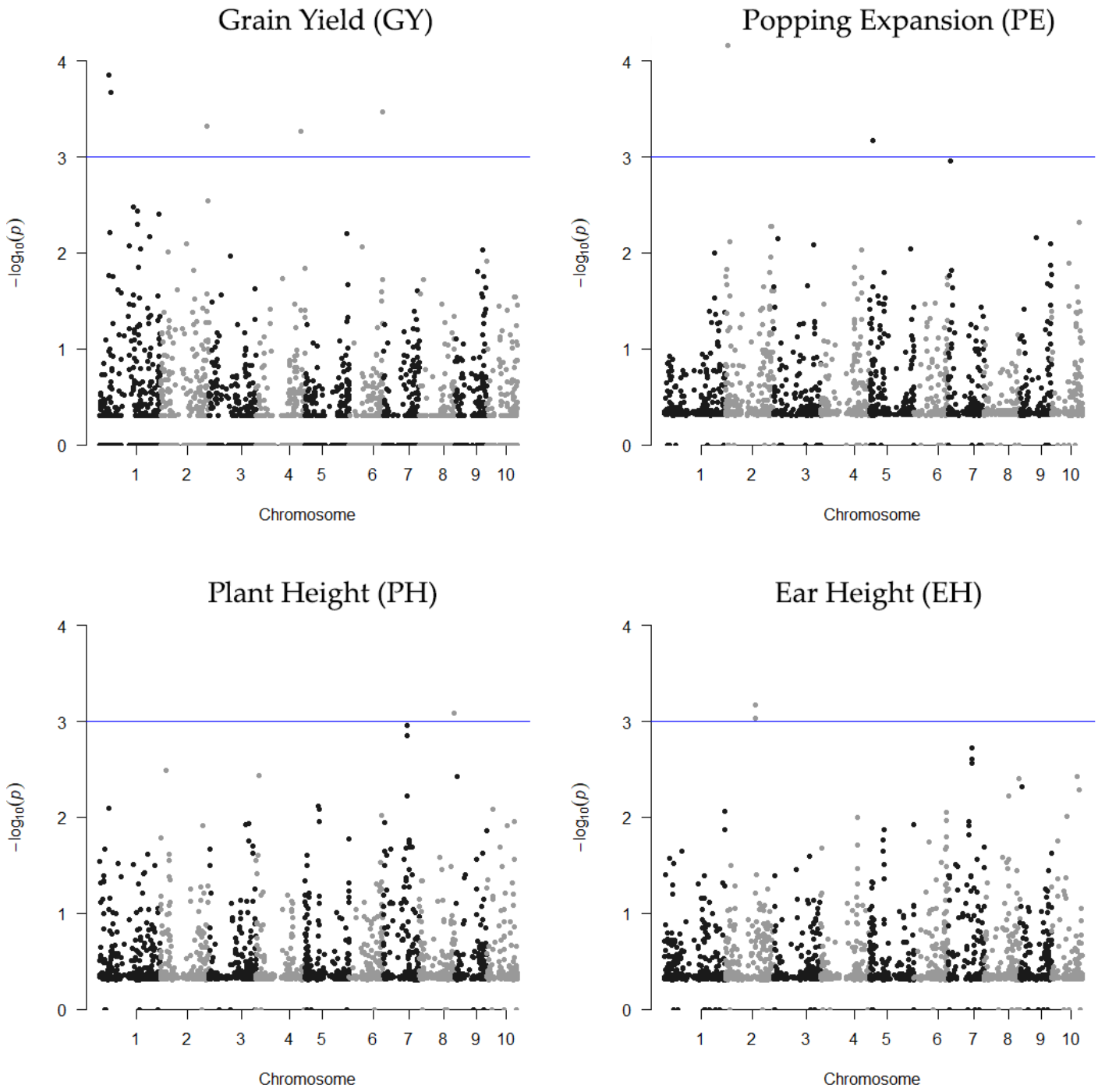

Figure 3. Manhattan plots of the statistical significance of the genomic regions associates with the GY, PE, PH, and EH traits in Campos dos Goytacazes (ENV1). The x-axis shows chromosomal positions and the y-axis shows $-\log _{10} p$-values. The blue horizontal line represents the genome-wide significance threshold ( $p$-value $\left.=1 \times 10^{-3}\right)$.
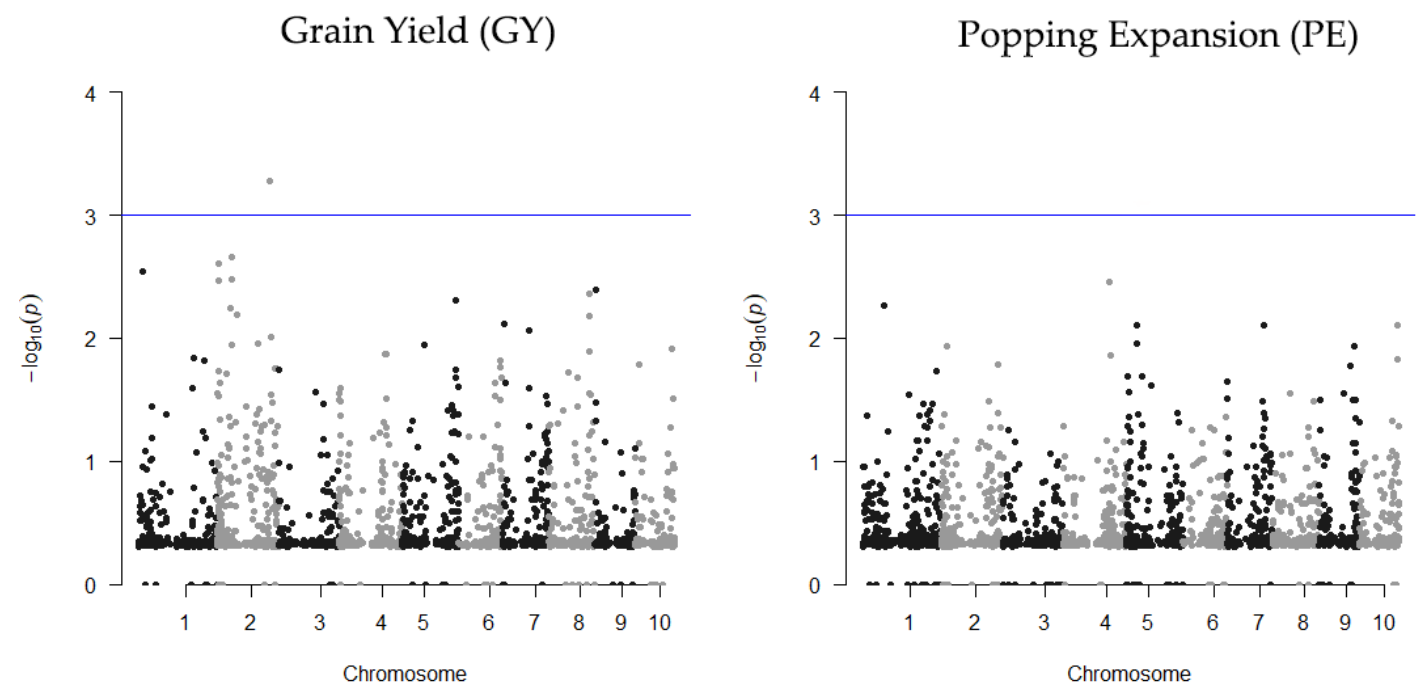

Figure 4. Cont. 

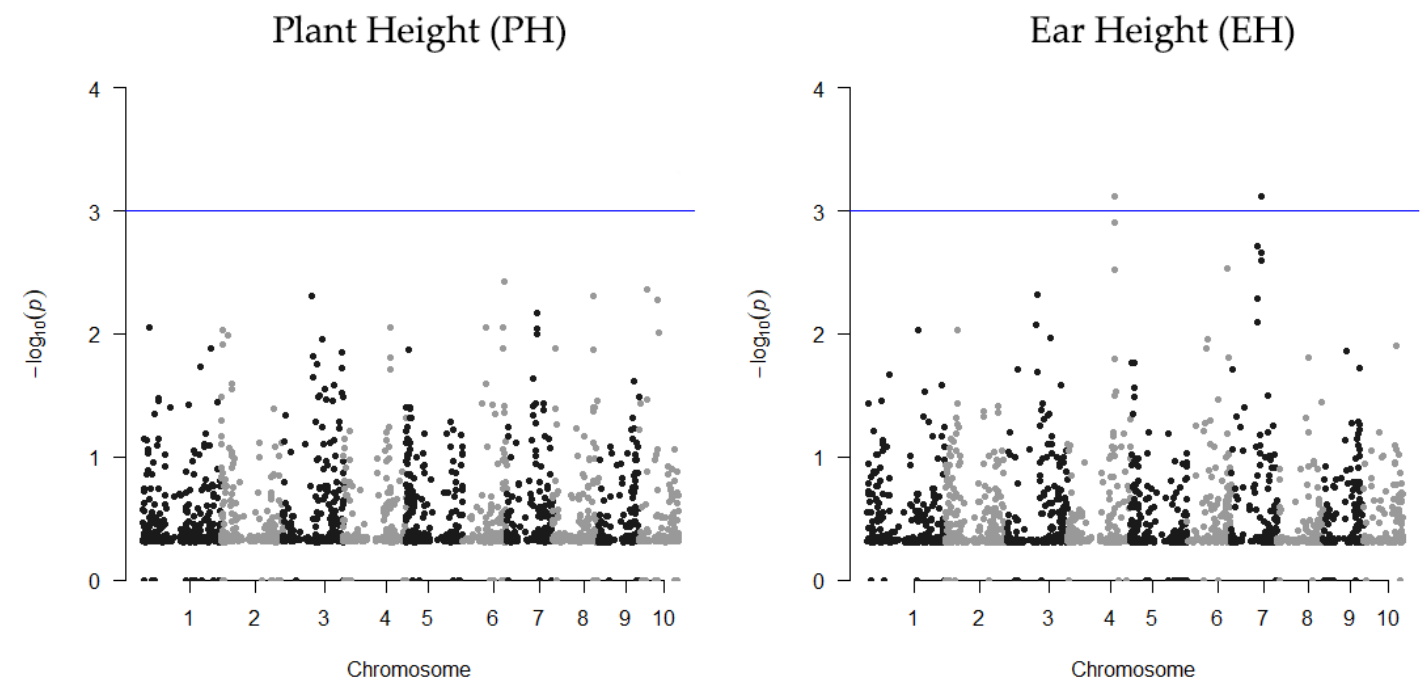

Figure 4. Manhattan plots of the statistical significance of the genomic regions associates with the GY, PE, PH, and EH traits in Itaocara (ENV2). The $x$-axis shows chromosomal positions and the $y$-axis shows $-\log _{10} p$-values. The blue horizontal line represents the genome-wide significance threshold $\left(p\right.$-value $\left.=1 \times 10^{-3}\right)$.

\subsection{Gene Identification in QTL Regions}

As the main findings by RHM in both environments, possible candidate genes were identified based on the physical position of reference genome B73 (Tables 1 and 2) and regions significantly associated with the traits. Forty-six candidate genes were found within these regions, of which thirty-seven candidate genes were found to be associated with GY, $\mathrm{PE}$, and PH of ENV1, and nine to the EH and GY traits in ENV2. Notably, in the PE (ENV1) and PH (ENV1), the regions 13388849-13488849 (chromosome 2) and 171723438-171823438 (chromosome 8 ) presented the largest number of associated candidate genes ( 8 and 7 , respectively).

Table 1. Candidate genes detected by regional heritability analysis for four traits of interest for popcorn in environment ENV1.

\begin{tabular}{|c|c|c|c|c|c|}
\hline Trait & * Chrom. & $\begin{array}{l}\text { Minor-Major Position } \\
\text { (Base Pairs) }\end{array}$ & Gene ID & Annotation & Putative Function \\
\hline GY & 1 & $48905387-49005387$ & GRMZM2G003984 & Lon-like ATP-dependent protease & Seed germination [28] \\
\hline GY & 1 & $56805387-56905387$ & GRMZM2G069618 & TPR domain-containing protein & Plant development [29] \\
\hline GY & 1 & $56855387-56955387$ & GRMZM2G353147 & $\begin{array}{l}\text { GTP diphosphokinase/stringent } \\
\text { factor }\end{array}$ & Plant fertilization [30] \\
\hline \multirow[b]{2}{*}{ GY } & \multirow[b]{2}{*}{6} & \multirow[b]{2}{*}{$165623194-165723194$} & GRMZM5G846343 & Protein of unknown function & ${ }^{* *}$ NA \\
\hline & & & GRMZM5G846057 & AP2 domain (AP2) & $\begin{array}{l}\text { Growth and development } \\
\text { of plant tissues [31] }\end{array}$ \\
\hline \multirow{2}{*}{ GY } & \multirow{2}{*}{2} & \multirow{2}{*}{$225088849-225188849$} & GRMZM2G037993 & $\begin{array}{l}\text { Respiratory burst oxidase homolog } \\
\text { protein a-related }\end{array}$ & Root development [32] \\
\hline & & & GRMZM2G015945 & $\begin{array}{l}\text { Respiratory burst oxidase homolog } \\
\text { protein } \mathrm{b}\end{array}$ & Pathogen resistance [33] \\
\hline \multirow[t]{4}{*}{ GY } & \multirow[t]{4}{*}{2} & \multirow[t]{4}{*}{$225138849-225238849$} & GRMZM2G414114 & $\begin{array}{c}\text { Dnaj domain (dnaj) //TCP family } \\
\text { transcription factor } \\
(\mathrm{TCP}) / / \text { transposase-associated } \\
\text { domain }\end{array}$ & $\begin{array}{c}\text { Growth of axillary organs } \\
\text { and corn ear formation } \\
\text { [34] }\end{array}$ \\
\hline & & & GRMZM2G114948 & Plant protein of unknown function & $* *$ NA \\
\hline & & & GRMZM2G023328 & $\begin{array}{l}\text { Arginine and glutamate-rich protein } \\
1 \text { (ARGLU1) }\end{array}$ & ${ }^{* *}$ NA \\
\hline & & & GRMZM2G023585 & Hira-interacting protein 3 & ** NA \\
\hline
\end{tabular}


Table 1. Cont.

\begin{tabular}{|c|c|c|c|c|c|}
\hline Trait & * Chrom. & $\begin{array}{l}\text { Minor-Major Position } \\
\text { (Base Pairs) }\end{array}$ & Gene ID & Annotation & Putative Function \\
\hline GY & 4 & 219528603-219628603 & GRMZM2G043242 & $\begin{array}{l}\text { Zinc finger cw-type coiled-coil } \\
\text { domain protein } 3\end{array}$ & $\begin{array}{l}\text { Plant immunity to } \\
\text { disease [35] }\end{array}$ \\
\hline GY & 4 & $219578603-219678603$ & GRMZM2G109159 & Reticulon-like protein & Seed filling [36] \\
\hline \multirow[t]{8}{*}{$\mathrm{PE}$} & \multirow[t]{4}{*}{2} & \multirow[t]{4}{*}{ 13388849-13488849 } & GRMZM5G886913 & Predicted membrane protein & $\begin{array}{l}\text { Essential for many } \\
\text { functions [37] }\end{array}$ \\
\hline & & & GRMZM2G051958 & $\begin{array}{c}\text { Phosphoenolpyruvate } \\
\text { carboxykinase ATP }\end{array}$ & $\begin{array}{l}\text { Involved in the coating of } \\
\text { seeds and cotyledons [38] }\end{array}$ \\
\hline & & & GRMZM2G354053 & Myosin heavy chain-related// & $\begin{array}{l}\text { Movement of the Golgi } \\
\text { complex and } \\
\text { mitochondria in plant } \\
\text { cells [39]. }\end{array}$ \\
\hline & & & GRMZM5G866405 & $\begin{array}{c}\text { Isoleucine-tRNA } \\
\text { ligase/Isoleucyl-tRNA synthetase }\end{array}$ & ${ }^{* *} \mathrm{NA}$ \\
\hline & & & GRMZM5G899760 & $\begin{array}{c}\text { GDP dissociation inhibitor } \\
\text { (GDI)/ / transcription initiation } \\
\text { factor IIA, }\end{array}$ & $\begin{array}{l}\text { Pollen germination and } \\
\text { tube growth }[40]\end{array}$ \\
\hline & & & GRMZM2G059791 & $\begin{array}{l}\text { 2-keto-3-deoxy-1-rhamnonate } \\
\text { aldolase }\end{array}$ & ** NA \\
\hline & & & GRMZM2G359331 & Myosin heavy chain-related & $\begin{array}{l}\text { Movement of the Golgi } \\
\text { complex and } \\
\text { mitochondria in plant } \\
\text { cells [39] }\end{array}$ \\
\hline & & & AC195235.3_FG003 & Phosphoglyceromutase & $\begin{array}{l}\text { Concentration increase in } \\
\text { iron-deficient Cucumis } \\
\text { sativus L. roots [41] }\end{array}$ \\
\hline \multirow[t]{2}{*}{ PE } & \multirow[t]{2}{*}{5} & \multirow[t]{2}{*}{$13560296-13660296$} & GRMZM2G461948 & Ubiquitin-protein ligase & ** NA \\
\hline & & & AC194618.2_FG008 & $\begin{array}{l}\text { DNA(??) homolog subfamily c } \\
\text { member }\end{array}$ & $\begin{array}{c}\text { Cold tolerance in } \\
\text { transgenic tomato plants } \\
\text { [42] }\end{array}$ \\
\hline \multirow[t]{5}{*}{ PE } & \multirow[t]{5}{*}{5} & \multirow[t]{5}{*}{$13560296-13660296$} & GRMZM2G461959 & $\begin{array}{l}\text { Serine/threonine-protein } \\
\text { phosphatase pp2a-1 catalytic }\end{array}$ & $\begin{array}{c}\text { Expressed in stems, } \\
\text { flowers, and roots of } \\
\text { Oryza sativa [43] }\end{array}$ \\
\hline & & & GRMZM2G461936 & $\begin{array}{l}\text { Translation initiation factor } 2 \mathrm{C} \\
\text { (eif-2C) }\end{array}$ & $\begin{array}{l}\text { Regulation of various } \\
\text { aspects of plant } \\
\text { development and their } \\
\text { interactions with the } \\
\text { environment [44] }\end{array}$ \\
\hline & & & GRMZM2G161242 & Protein Y55F3AM.3, isoform a & $* * \mathrm{NA}$ \\
\hline & & & GRMZM2G161222 & $\begin{array}{c}\text { Serine/threonine-protein } \\
\text { phosphatase 2a } 57 \mathrm{kDa} \text { regulatory } \\
\text { subunit } \beta^{\prime} \text { alpha isoform }\end{array}$ & $\begin{array}{l}\text { Control of biotic and } \\
\text { abiotic stress responses in } \\
\text { plants [45] }\end{array}$ \\
\hline & & & GRMZM2G148130 & $\begin{array}{l}\text { Ubiquitin-conjugating enzyme } \\
\text { E2 } 16\end{array}$ & $\begin{array}{l}\text { Maintenance of normal } \\
\text { maize growth under } \\
\text { stress conditions [46] }\end{array}$ \\
\hline \multirow[t]{2}{*}{$\mathrm{PE}$} & \multirow[t]{2}{*}{5} & \multirow[t]{2}{*}{$13610296-13710296$} & GRMZM2G148098 & $\begin{array}{l}\text { Homeobox protein transcription } \\
\text { factors }\end{array}$ & $\begin{array}{c}\text { Maintenance of adequate } \\
\text { meristem and organ } \\
\text { initiation [47] }\end{array}$ \\
\hline & & & GRMZM2G122185 & Pre-mRNA splicing factor & $\begin{array}{l}\text { Temperature signaling in } \\
\text { plants [48] }\end{array}$ \\
\hline \multirow[t]{4}{*}{$\mathrm{PH}$} & \multirow[t]{4}{*}{8} & \multirow[t]{4}{*}{ 171723438-171823438 } & GRMZM2G133249 & Insulysin (IDE, ide) & $\begin{array}{c}\text { Beta-amyloid (A } \beta \text { ) } \\
\text { degradation [49] }\end{array}$ \\
\hline & & & GRMZM2G562929 & Proteasome subunit alpha type- 4 & ** NA \\
\hline & & & GRMZM2G133175 & $\begin{array}{c}\text { Cysteine-rich TM module stress } \\
\text { tolerance (CYSTM) }\end{array}$ & $\begin{array}{l}\text { Tolerance to heavy } \\
\text { metals, such as cadmium } \\
\text { and copper [50] }\end{array}$ \\
\hline & & & GRMZM2G133029 & Aspartyl protease family protein & $\begin{array}{l}\text { Plant defense against } \\
\text { fungi [51] }\end{array}$ \\
\hline
\end{tabular}


Table 1. Cont.

\begin{tabular}{|c|c|c|c|c|c|}
\hline Trait & * Chrom. & $\begin{array}{c}\text { Minor-Major Position } \\
\text { (Base Pairs) }\end{array}$ & Gene ID & Annotation & Putative Function \\
\hline & & & GRMZM2G132991 & $\begin{array}{l}\text { Conserved oligomeric Golgi } \\
\text { complex subunit } 1\end{array}$ & $\begin{array}{l}\text { Resistance penetration in } \\
\text { barley by the barley } \\
\text { mildew fungus [52] }\end{array}$ \\
\hline & & & GRMZM2G132978 & Pthr36737:sf1-expressed protein & ** NA \\
\hline & & & GRMZM2G434363 & $\begin{array}{l}\text { Protein kinase domain } \\
\text { (Pkinase)//salt stress } \\
\text { response/antifungal } \\
\text { (stress-antifungal) }\end{array}$ & $\begin{array}{c}\text { Response to salt stress } \\
\text { [53] }\end{array}$ \\
\hline
\end{tabular}

*Chrom: chromosome; ${ }^{* *}$ NA: not applicable.

Table 2. Candidate genes detected by regional heritability analysis for four traits of interest for popcorn in environment ENV2.

\begin{tabular}{|c|c|c|c|c|c|}
\hline Trait & * Chrom. & $\begin{array}{l}\text { Minor-Major Position } \\
\text { (Base Pairs) }\end{array}$ & Gene ID & Annotation & Putative Function \\
\hline $\mathrm{EH}$ & 7 & $115031917-115131917$ & GRMZM2G022095 & $\begin{array}{l}\text { rRNA N-glycosylase/rRNA } \\
\text { N-glycosidase }\end{array}$ & $\begin{array}{l}\text { Antiviral, antifungal, and } \\
\text { insecticidal activities and } \\
\text { their expression in plants } \\
\text { are increased under stress } \\
\text { conditions [54] }\end{array}$ \\
\hline \multirow[t]{2}{*}{$\mathrm{EH}$} & \multirow[t]{2}{*}{7} & \multirow[t]{2}{*}{ 115081917-115181917 } & GRMZM5G837058 & $\begin{array}{l}\text { Golgi SNAP receptor complex } \\
\text { member } 1-1\end{array}$ & $\begin{array}{l}\text { Transport from Golgi } \\
\text { complex to the } \\
\text { endoplasmic reticulum } \\
\text { [55] }\end{array}$ \\
\hline & & & GRMZM2G071059 & $\begin{array}{c}\text { CCR4-NOT transcription complex } \\
\text { subunit } 7 / 8 \text { (CNOT7_8, CAF1, } \\
\text { POP2) }\end{array}$ & $\begin{array}{l}\text { Responses to abiotic } \\
\text { stress [56] }\end{array}$ \\
\hline \multirow[t]{5}{*}{$\mathrm{EH}$} & \multirow[t]{5}{*}{4} & \multirow[t]{5}{*}{$178478603-178578603$} & GRMZM2G170313 & $\begin{array}{l}\text { Prolyl-tRNA synthetase associated } \\
\text { domain-containing protein 1-related }\end{array}$ & ** NA \\
\hline & & & GRMZM2G473016 & Ring zinc finger protein & $\begin{array}{l}\text { Increased stomatal } \\
\text { opening [57] }\end{array}$ \\
\hline & & & GRMZM2G060630 & $\begin{array}{l}\text { Solute carrier family } 25 \\
\text { (mitochondrial phosphate } \\
\text { transporter), member } 3\end{array}$ & $\begin{array}{l}\text { Normal growth and } \\
\text { development of } \\
\text { Arabidopsis [58] }\end{array}$ \\
\hline & & & GRMZM2G060554 & $\begin{array}{l}\text { Remorin, C-terminal region } \\
\text { (Remorin_C) }\end{array}$ & $\begin{array}{l}\text { Resistance to } \\
\text { helminthosporium in } \\
\text { corn [59] }\end{array}$ \\
\hline & & & GRMZM2G356046 & $\begin{array}{c}\text { Mannan endo-1,4-beta-mannosidase } \\
\text { (MAN) }\end{array}$ & Seed germination [60] \\
\hline GY & 2 & 200888849-200988849 & GRMZM2G024622 & RNA polymerase II ctd phosphatase & $\begin{array}{l}\text { Increased tolerance to } \\
\text { thermal stress [61] }\end{array}$ \\
\hline
\end{tabular}

* Chrom: chromosome; ${ }^{* *}$ NA: not applicable.

\section{Discussion}

\subsection{Linkage Disequilibrium and Heritability Captured by RHM}

Half of the LD decay varied among chromosomes $(76-151 \mathrm{~Kb})$, which suggests differences in their rate of recombination [18]. The linkage disequilibrium in allogamous species, e.g., in maize, decays over relatively shorter distances than in autogamous species [62]. However, in an evaluation of 64 corn lines [63], it was observed that the average LD decay length in all of them was 80-100 kb [63]. Similarly, was observed that in 144 maize lines, the average LD decay for all chromosomes was around $200 \mathrm{~kb}$ [64].

Heritability estimated based on RHM was low for most traits and in both environments (Supplementary Table S2), with ENV2 presenting the lowest heritability at 0.078 for GY.

In ENV1, for GY-one of the key traits of interest in popcorn—a series of heritability values were obtained, which ranged from $11 \%$ to $93 \%$. This variation may be due to 
population effects, environmental factors, or experimental precision [24], or, more likely, genome partitioning caused by the RHM methodology. Moreover, simulating data of parental lines, genotypes, and phenotypes $F_{1}$ and $F_{2}$ and using the maximum likelihood approach by interval mapping for low heritability QTLs and high SNP density, obtained a value of approximately $95 \%$ heritability for GY when using a sample number of 200 [65].

Previous studies have reported that the trait heritability of GY varies from low to moderate [66,67], indicating a lower additive genetic control and high environmental influence. However, other research has claimed that the heritability of GY is high and significant $[68,69]$ and suggested, therefore, that these values depend on the population under study. In the UENF-14 population intrapopulation recurrent selection program, it was observed that heritability remained stable in cycles 4,5 and $6(45.97 \%, 51.94 \%$, and $45.04 \%$, respectively) [70]. In addition, a heritability of $91 \%$ for GY was observed in cycle 9 of the same population [71]. In research carried out by Resende and collaborators [24], the estimated genomic heritability captured a relatively large proportion (72\%) of the total heritability of the traits. This was useful in identifying favorable alleles for GY of Phaseolus vulgaris $\mathrm{L}$, demonstrating that the RHM method was effective in detecting the hereditary portion of the trait in the population.

On the other hand, in ENV1, the inheritable proportion of total variability of $\mathrm{PH}$ and $\mathrm{EH}$ traits was the lowest (Supplementary Table S2). Some hypotheses can be raised in this regard, e.g., the fact that the traits $\mathrm{EH}$ and $\mathrm{PH}$ are directly correlated and have a high heritability [7]. However, when partitioning the genome, as in the RHM method, the values within each genomic window may be too low to be detected by the analysis. The same is not true for GY, for which the highest heritability values were recorded by RHM, and which, despite the strong environmental influence on it [66,67], has been shown to remain stable in successive cycles of intrapopulation recurrent selection in the population sampled here $[70,71]$.

\subsection{RHM Analysis and Candidate Genes}

Among the QTLs observed in ENV1, some genes were considered to be biologically important due to their encoded proteins and proven participation in the studied traits.

The GRMZM2G069618 gene reported to be involved in the expression of GY encodes the protein containing the tetratricopeptide repeat domain (TPR). The TPR is involved with numerous outstanding functions in plant organisms, for example, hybrid sterility in rice [72], hormonal signaling and stress [73], root development [29], and failure of endosperm development, with a consequent reduction in seed number [74]. In addition, in rice, TPR may be involved in amylose content, grain appearance, physical and chemical properties [75], and grain size and starch quality [76]. The results found in this study corroborate the hypotheses of TPR can be directly involved with the expression of kernel weight in popcorn, consequently influencing the GY trait.

The GRMZM5G846057 gene, linked to the GY trait, is related to the AP2 domain (AP2) protein. APETALA2/ethylene proteins (AP2/EREBPs) are the main regulators of responses to plant development, growth, and stress $[77,78]$. AP2/EREBP genes play a crucial role in responding to various environmental stresses in cotton [77]. ERF transcription factors are AP2/EREBP proteins that contain only one AP2 domain and constitute the largest subfamily of the AP2/EREBP family [78]. Although a direct relationship has not been identified between GRMZM5G846057 and GY, this trait seems to be directly influenced by abiotic stress, as reported in several studies [79-83]. Therefore, it is possible to suggest that the trait GY is related to responses to stresses and when there is a reduction in grain yield, there is also overexpression of the GRMZM5G846057 gene, which codes AP2/EREBP, related to stresses in plants.

The GRMZM2G414114 gene, which is related to the expression of the protein DNAj (??) domain/ /TCP family transcription factor//Transposase-associated domain, is involved with grain yield. This protein, called TCT, refers to transcription factors observed in plants and is involved in the growth and development of several species [84], including the 
growth of axillary organs and corn ear formation [34], formation of the shoot meristem and shoot development of Arabidopsis [85], and development or ripening of tomato fruits [86]. Thus, the involvement of TCP in the development process of popcorn kernels can be suggested, since kernel weight is directly related to the total trait yield, represented here by the acronym GY.

The GRMZM2G051958 gene, responsible for coding the enzyme phosphoenolpyruvate carboxykinase ATP (PEPCK), is involved in the expression of the trait PE. Studies report that this protein plays a significant role in the photosynthesis of $\mathrm{C} 4$ plants of the Poaceae family, in which corn is inserted [87], as well as the increase in the photosynthetic rate of wheat plants with a significant increase in the grain yield of the species [88,89]. In addition, research reports the importance of the enzyme phosphoenolpyruvate carboxykinase in the development of seeds of species such as peas (Pisum sativum), highly involved in the coating of seeds and cotyledons [38]. An overexpression of PEPCK in common bean seeds was found to raise protein accumulation in the organ [90].

GRMZM2G069618, GRMZM2G414114, and GRMZM2G051958 encode proteins that would directly affect GY by regulating the weight and size of grains, increase in the photosynthetic rate, and the physical and chemical properties of popcorn. Moreover, these genes are involved in the growth and development of plants, and the development process of popcorn kernels, key aspects in the GY. Particularly, GRMZM2G051958 has shown a significant increase in the grain yield in wheat through an increase in the photosynthetic rate. On the other hand, GRMZM5G846057 encodes a protein AP2, which regulates the GY in conditions of abiotic stress. In this sense, $\mathrm{Xu}$ et al. [91] overexpressed the ZmCBF3 (a maize AP2/ERF-type transcription factor) in rice plants, and they showed that tolerance to drought stress was improved without not affect the grain yield. Therefore, advancing the knowledge of this gene in popcorn can help preserve GY under conditions of drought stress, an important aspect considering current climatic conditions.

A relationship between PH and the GRMZM2G133175 gene, which encodes a cysteinerich TM module stress tolerance (CYSTM), was observed. The cysteine-rich transmembrane module CYSTM, commonly found in eukaryotes, is composed of a small family of molecular proteins [92]. The CYSTM genes exhibit a broad and constant expression pattern that may play vital roles in plant growth and development [92]. Moreover, this module was responsible for conferring tolerance to heavy metals such as cadmium and copper in Digitaria ciliaris and Oryza sativa [50], and resistance to abiotic stress in Arabidopsis thaliana [92]. Xu et al. [92] suggest that the CYSTM family, as newly discovered small peptides, plays multiple roles in plant growth and development, especially in response to abiotic stresses.

In ENV2, the GRMZM2G060630 gene, which encodes the mitochondrial phosphate transporter (MPT) member 3 protein, was related to EH. Mitochondrial phosphate transporters have been identified as responsible for plant responses to salt stress in Arabidopsis thaliana [93] and indispensable for the growth and development of plants of this species [58]. This led to the assumption of their direct involvement in growth related to the insertion height of the first ear (EH) in popcorn plants. Jia et al. [58] suggested that MPT3 played important role in regulating plant growth and development in Arabidopsis.

The RHM approach to the analysis of SNP data has the potential to explain part of the missing heritability by capturing QTL variance from small regions of the genome, which escape the standard association, single SNP-based studies. For example, Mafra et al. [8], in this same population, observed that heritability estimates for the SNP markers allowed them to capture $<0.01$ in GY for ENV1, while the RHM method registered a heritability between 0.11 and 0.93 , capturing the missing heritability in this trait. Therefore, the RHM strategy used in the present study was proven to be useful and robust, complementary to other association analyses. Moreover, RHM analysis identified QTLs and candidate genes related to traits of interest, which can be incorporated into breeding programs and genomic selection strategies in maize. 


\section{Materials and Methods}

\subsection{Study Population and Phenotypic Evaluations}

The study was carried out in August 2016, at the Research Station of the Antônio Sarlo State College of Agriculture ( $\left.21^{\circ} 43^{\prime} 14.8^{\prime \prime} \mathrm{S}, 41^{\circ} 20^{\prime} 38.3^{\prime \prime} \mathrm{W}\right)$, in the county of Campos dos Goytacazes (Rio de Janeiro-RJ) (hereafter ENV1), and on an experimental field of the State University of Northern Rio de Janeiro-UENF $\left(21^{\circ} 38^{\prime} 45.2 \mathrm{~S} 42^{\circ} 03^{\prime} 16.3^{\prime \prime} \mathrm{W}\right)$, on the Ilha Barra do Pomba, county of Itaocara (Rio de Janeiro-RJ) (henceforth ENV2). The ENV1 has a dry tropical climate with an average annual temperature around $24{ }^{\circ} \mathrm{C}$ and annual precipitation of $1112 \mathrm{~mm}$ [94], while ENV2 has a warm climate with an average annual temperature around $22.5^{\circ} \mathrm{C}$ and annual precipitation of $1041 \mathrm{~mm}$ [95].

The study population consisted of $98 \mathrm{~S} 1$ families derived from the 9th recurrent selection cycle (C-9) of the open-pollinated variety UENF-14 [96-98], which was developed from five cycles of recurrent selection of the population UNB-2U. The UNB-2U was derived from UNB-2 after two mass selection cycles in Campos dos Goytacazes, Rio de Janeiro, Brazil [99]. After five cycles of intrapopulation recurrent selection of UNB-2U, the cultivar UENF-14 was launched [96], and today it is in the 9th cycle of recurrent selection (C-9), used in this research.

The cycles of recurrent selection to obtain the studied population were obtained through the strategies described in Table 3, with their respective gains in PE\% and GY\%.

Table 3. Genetic gains across recurrent selection cycles in the UNB-2U population.

\begin{tabular}{ccccc}
\hline Cycle & Reference & Strategy & PE (\%) * & GY (\%) * \\
\hline $1^{\circ}$ & Daros et al. [97] & Full-sib families & 10.39 & 4.69 \\
$2^{\circ}$ & Daros et al. [98] & Inbred families (S $\left.)_{1}\right)$ & 17.8 & 26.95 \\
$3^{\circ}$ & Santos et al. [99] & Half-sibling families & 7.16 & 10.00 \\
$4^{\circ}$ & Freitas Júnior et al. [100] & Full-sib families & 10.58 & 7.71 \\
$5^{\circ}$ & Rangel et al. [101] & Full-sib families & 6.01 & 8.53 \\
$6^{\circ}$ & Ribeiro et al. [69] & Full-sib families & 10.97 & 15.30 \\
$7^{\circ}$ & Freitas et al. [102] & Full-sib families & 5.11 & 7.78 \\
$8^{\circ}$ & Guimarães et al. [71] & Full-sib families & 3.61 & 4.60 \\
\hline
\end{tabular}

Cycle: selection cycle; Reference: started by the first author of the publication of the article referring to the respective cycle; PE: kernel popping expansion; GY: grain yield; * Genetic gains (in percentage) for each selection cycle.

The tests were designed in incomplete blocks with three orthogonal repetitions. Seeds of each family were sown in a $5 \mathrm{~m}$ long row, at a spacing of $0.90 \mathrm{~m}$ between rows and $0.20 \mathrm{~m}$ between plants. When necessary, cultural treatments were carried out as recommended for the crop.

At both locations, the main traits of agronomic interest for the crop were measured: grain yield (GY, $\mathrm{Kg} / \mathrm{ha})$, kernel popping expansion (PE, $\mathrm{mL} / \mathrm{g})$, plant height $(\mathrm{PH}, \mathrm{cm})$, and the first ear height $(\mathrm{EH}, \mathrm{cm})$. GY was measured after the threshing process of all ears in the plot, where the weight (weighed on a precision scale) in $\mathrm{Kg}$ of the kernels per plot was transformed to $\mathrm{kg} \mathrm{ha}^{-1}$. PE was measured by weighing $30 \mathrm{~g}$ kernels per plot on a precision scale; then, these were inserted into kraft paper bags and microwaved for $2 \min 20 \mathrm{~s}$. Afterward, the popped kernels were filled in $2000 \mathrm{~mL}$ beakers, and the resulting volume was divided by the initial kernel weight (30 g of grains). PH was measured from the soil level to the flag leaf insertion in six healthy plants per plot (with a ruler). Similarly, EH was measured in six healthy plants per plot, from the soil level to the insertion of the first ear (with a ruler). Data from the phenotypic evaluations are shown in Supplementary Table S1. The phenotypic data were adjusted using the lme4 package [103] in R software [104], by the following mixed model:

$$
y=X \beta_{1}+Z_{1} b+Z_{2} p+e
$$


where $y$ is the phenotype vector of a given trait; $\beta_{1}$ is the vector with fixed effects, including intercept, repetition, and covariates such as the number of plants per plot, counted immediately after thinning and kernel moisture, for the traits GY and PE [8]; $b$ is a vector of block effects within replications; $p$ is the progeny effect, assumed as fixed to estimate the adjusted means (with package LSMeans) [105]; $e$ is the vector of residual effects of the model. $X$ is the incidence matrix of systematic fixed effects, and $Z_{1,2}$ are incidence matrices of random effects.

\subsection{Genotyping}

Genomic DNA was extracted from the young leaves of 200 plants, from the breeding population, using the standard CTAB method of Doyle and Doyle [106] with modifications. The collected DNA samples were sent to the company Rapid Genomics LLC for sequencing by the Capture Seq method [26], with 5000 well-distributed probes in the maize reference genome. These probes are selected and obtained from known reference regions, available in the database. In the Capture Seq method, the genomic DNA is fragmented to hybridize with barcode adapters. After the probes have captured the target fragments amplified, the libraries are assembled for sequencing. Subsequently, the sequencing data file is filtered by individual barcodes and is aligned by the reference genome.

\subsection{Genetic Aspects of the Population}

From the panel of 10,507 SNPs and 196 individuals, the Genetic Relationship Matrix (GRM) was calculated, with the rrBLUP package [107], based on the algorithm of VanRaden [108]. This same panel of genotypic data was used to estimate the linkage disequilibrium (LD), based on $r^{2}$ statistics, using PLINK software [109]. To analyze the LD decay across the genome, the nonlinear model proposed by Hill and Weir [110] was fitted, using the nlm function of the R language [104].

\subsection{Regional Heritability Mapping}

Regional heritability mapping provides heritability estimates for genomic segments containing common and rare allelic effects [24]. The RHM model presented in the following equation was adjusted using the Regress package [111] in R software [104].

$$
y=X \beta_{1}+Z_{1} b+Z_{2} r+Z_{3} u+e
$$

where $y$ is the vector with the phenotypes of a given trait; $\beta_{1}$ is the vector with fixed effects-intercept, repetition and covariables such as the number of plants per plot, counted immediately after thinning and kernel moisture for the traits GY and PE; $b$ is the vector of block effects; $r$ is the vector of random regional genomic additive effects; $u$ is the vector of polygenic effects; $e$ is the residual effect vector of the model. $X$ is the incidence matrix of systematic fixed effects, and $Z_{1,2,3}$ are incidence matrices of random effects.

The following was assumed:

$$
\begin{gathered}
b\left|\sigma_{b}^{2} \sim N\left(0, I \sigma_{b}^{2}\right) ; r\right| \sigma_{r}^{2} \sim N\left(0, G_{r e g} \sigma_{r}^{2}\right) ; u\left|\sigma_{u}^{2} \sim N\left(0, G \sigma_{u}^{2}\right) ; e\right| \sigma_{e}^{2} \sim N\left(0, I \sigma_{e}^{2}\right) ; \\
\operatorname{cov}\left(u, b^{\prime}\right)=\operatorname{cov}\left(u, e^{\prime}\right)=\operatorname{cov}\left(b, e^{\prime}\right)=0
\end{gathered}
$$

where $G$ is the genomic matrix of kinship, calculated with the rrBLUP package [107], based on the algorithm of VanRaden [108]; Greg is a matrix similar to $G$, but uses a subset of matrix $W(W$ is the SNP marker incidence matrix assuming $W \subset(-1,0,1))$. These subsets were determined by $100 \mathrm{~kb}$ long genomic "windows" or "regions", with overlapping stretches of $50 \mathrm{~kb}$ (for example, the first three regions are $0-100,50-150$, and 100-150 kb), corresponding to the estimated LD-see Results section); I $b$ and In are identity matrices with the same order as that of the number of incomplete blocks and number of observations, respectively; $\sigma_{b}^{2}, \sigma_{r}^{2}, \sigma_{u}^{2}$, and $\sigma_{e}^{2}$ are the components of variance associated with $b, r, u$, and $e$, respectively. These components were estimated by REML, using the average information (AI) algorithm. 
RHM was adjusted by the Regress package [111], in language R 3.2.3 [103], according to the procedure proposed by Resende [18]. Significance testing was based on a likelihood ratio test statistic (LRT) with $p$-value $\leq 0.001$, or $-\log _{10}$ ( $p$-value) $\geq 3$.

For each segment of the genomic window, the regional heritability was determined by the following equation:

$$
\operatorname{cov}\left(u, b^{\prime}\right)=\operatorname{cov}\left(u, e^{\prime}\right)=\operatorname{cov}\left(b, e^{\prime}\right)=0
$$

where $\sigma_{r}^{2}, \sigma_{g}^{2}$, and $\sigma_{e}^{2}$ are the components of variance associated with $r, g$, and $e$, respectively.

\subsection{Identification of Candidate Genes}

The QTLs identified by RHM analysis were subjected to gene identification analysis, using the public maize genome data set, based on the reference genome B73 version 3 (gene annotation in the B73 Zea mays AGPv3 assembly) [112]. Functional gene annotations were identified using the Phytozome genome browser (https:/ / phytozome.jgi.doe.gov/ $\mathrm{pz} /$ portal.html, (accessed on 10 November 2020)). The gene search regions were defined according to the start and end position of each region. The genes detected within these regions were defined as candidate genes.

\section{Conclusions}

RHM allowed us to combine common and rare variants within the same analysis, which provided valuable information on the genetic architecture of yield and growth traits. It was confirmed that RHM has the potential to explain some portion of missing heritability by capturing variance caused by QTL with low MAF and multiple independent QTL within a region, as determined for grain yield. Moreover, the genomic regions identified by RHM allowed further examination towards candidate genes discovery. In this regard, a total of 22 genomic regions were identified in both tropical environments, which may be related to the adaptability of the genotypes to each environment. Subsequent gene identification study revealed associations with several genes with a known function in plants. Forty-six candidate genes were associated with these genomic regions, of which seven are considered to be biologically important, encoding proteins that participate in plant development processes, and suggesting different roles in the performance of functions related to popcorn growth and yield. The QTLs and candidate genes detected in this study broaden the knowledge on the molecular basis of these important agronomic traits and could potentially help to increase the efficiency of popcorn breeding programs, creating new opportunities for the development and selection of elite breeding genotypes.

Supplementary Materials: The following are available online at https:/ /www.mdpi.com/article/10 $.3390 /$ plants10091845/s1, Table S1: Phenotypic data of 98 genotypes evaluated in the environments of Campos dos Goytacazes (ENV1) and Itaocara (ENV2).Table S2: Genomic regions detected by regional heritability mapping (RHM) in $0.1 \mathrm{Mb}$ genomic segments with a $0.05 \mathrm{Mb}$ sliding window for traits grain yield $(\mathrm{GY})$, kernel popping expansion (PE), plant height $(\mathrm{PH})$, and ear height $(\mathrm{EH})$ evaluated in a popcorn population under intrapopulation recurrent selection in the environments of Campos dos Goytacazes (ENV1) and Itaocara (ENV2).

Author Contributions: Conceptualization, methodology, investigation and formal analysis, G.S.M., J.E.d.A.F., A.T.d.A.J. and S.H.K.; writing—original draft preparation, G.S.M.; data curation, G.S.M., J.E.d.A.F. and C.C.G.C.; writing-original draft preparation, project administration and funding acquisition, A.T.d.A.J.; software, resources, validation, and formal analysis, C.M. and F.M.-P.; conceptualization, V.J.d.L., D.R.d.S.J. and J.T.L.; writing-review and editing, C.M., P.H.A.D.S., T.d.O.S., R.B.B., U.A.d.O. and S.A.; conceptualization, S.A., V.B.P., A.P.V. and C.C.G.C.; supervision, A.T.d.A.J. and F.M.-P. All authors have read and agreed to the published version of the manuscript.

Funding: This study was partially financed by the Coordination for the Improvement of Higher Education Personnel (CAPES), Brazil, finance code 001, to D.R.d.S.J., J.T.L., R.B.B., and U.T.L. Funding was also provided by Rio de Janeiro State Research Support Foundation (FAPERJ), with the project numbers E26/200.585/2016 and E26/201.616/2018 to G.S.M. and E26/ 202.310/2017 to A.T.d.A.J. 
Bayer provided support in the form of a salary to the author J.E.d.A.F. but did not have any additional role in the study design, data collection or analysis; a decision to publish the results; or preparation of the manuscript.

Institutional Review Board Statement: Not applicable.

Data Availability Statement: The data presented in this study are openly available in FigShare at https:/ / doi.org/10.6084/m9.figshare.12867062.v1, (accessed on 25 March 2021).

Acknowledgments: G.S.M. thanks the Rio de Janeiro State Research Support Foundation (FAPERJ) for providing a doctoral scholarship. F.M.-P. and S.A. acknowledge the Chilean National Fund for Scientific and Technological Development (FONDECYT) grant number 1201973.

Conflicts of Interest: The authors declare that they have no conflict of interest.

\section{References}

1. Maldonado, C.; Mora, F.; Scapim, C.A.; Coan, M. Genome-wide haplotype-based association analysis of key traits of plant lodging and architecture of maize identifies major determinants for leaf angle: HapLA4. PLoS ONE 2019, 14, e0212925. [CrossRef]

2. FAO. FAOSTAT-Crops. 2017. Available online: http://www.fao.org/faostat/en/\#data/QC (accessed on 20 May 2021).

3. Paraginski, R.T.; Ziegler, V.; Ferreira, C.D.; Colussi, R.; Gutkoski, L.C.; Zavareze, E.D.R.; Elias, M.C. Properties of popcorn starch expanded in a microwave, with and without the presence of vegetable oil. J. Food Process. Pres. 2017, 41, e13142. [CrossRef]

4. Vittorazzi, C.; Junior, A.A.; Guimarães, A.G.; Viana, A.P.; Silva, F.H.L.; Pena, G.F.; Daher, R.F.; Gerhardt, I.F.S.; Oliveira, G.H.F.; Pereira, M.G. Indices estimated using REML/BLUP and introduction of a super-trait for the selection of progenies in popcorn. Genet. Mol. Res. 2017, 16, gmr16039769. [CrossRef]

5. Lu, H.-J.; Bernardo, R.; Ohm, H. Mapping QTL for popping expansion volume in popcorn with simple sequence repeat markers. Theor. Appl. Genet. 2003, 106, 423-427. [CrossRef]

6. Coan, M.M.D.; Pinto, R.J.B.; Kuki, M.C.; Amaral Júnior, A.T.; Figueiredo, A.S.T.; Scapim, C.A.; Warburton, M. Inheritance Study for Popping Expansion in Popcorn vs. Flint Corn Genotypes. Agron. J. 2019, 111, 2174-2183. [CrossRef]

7. Li, Y.; Dong, Y.; Niu, S.; Cui, D. The genetic relationship among plant-height traits found using multiple-trait QTL mapping of a dent corn and popcorn cross. Genome 2007, 50, 357-364. [CrossRef]

8. Mafra, G.S.; do Amaral Júnior, A.T.; de Almeida Filho, J.E.; Vivas, M.; Santos, P.H.A.D.; Santos, J.S.; Pena, G.F.; de Lima, V.J.; Kamphorst, S.H.; de Oliveira, F.T.; et al. SNP-based mixed model association of growth- and yield-related traits in popcorn. PLoS ONE 2019, 14, e0218552. [CrossRef]

9. Babu, R.; Nair, S.K.; Kumar, A.; Rao, H.S.; Verma, P.; Gahalain, A.; Singh, I.S.; Gupta, H.S. Mapping QTLs for popping ability in a popcorn $\times$ flint corn cross. Theor. Appl. Genet. 2006, 112, 1392-1399. [CrossRef] [PubMed]

10. Thakur, S.; Kumar, R.; Vikal, Y.; Vyas, P.; Sheikh, I.; Dhaliwal, H.S. Molecular mapping of popping volume QTL in popcorn (Zea maize L.). J. Plant Biochem. Biotechnol. 2021, 30, 496-503. [CrossRef]

11. Li, Y.L.; Dong, Y.B.; Cui, D.Q.; Wang, Y.Z.; Liu, Y.Y.; Wei, M.G.; Li, X.H. The genetic relationship between popping expansion volume and two yield components in popcorn using unconditional and conditional QTL analysis. Euphytica 2008, 162, 345-351. [CrossRef]

12. Dell'Acqua, M.; Gatti, D.M.; Pea, G.; Cattonaro, F.; Coppens, F.; Magris, G.; Hlaing, A.L.; Aung, H.H.; Nelissen, H.; Baute, J.; et al. Genetic properties of the MAGIC maize population: A new platform for high definition QTL mapping in Zea mays. Genome Biol. 2015, 16, 167. [CrossRef]

13. Li, J.; Li, D.; Espinosa, C.Z.; Pastor, V.T.; Rasheed, A.; Rojas, N.P.; Wang, J.; Varela, A.S.; Carolina de Almeida Silva, N.; Schnable, P.S.; et al. Genome-wide analyses reveal footprints of divergent selection and popping-related traits in CIMMYT's maize inbred lines. J. Exp. Bot. 2021, 72, 1307-1320. [CrossRef]

14. Valenzuela, C.E.; Ballesta, P.; Ahmar, S.; Fiaz, S.; Heidari, P.; Maldonado, C.; Mora-Poblete, F. Haplotype-and SNP-Based GWAS for Growth and Wood Quality Traits in Eucalyptus cladocalyx Trees under Arid Conditions. Plants 2021, 10, 148. [CrossRef]

15. Maldonado, C.; Mora, F.; Bertagna, F.A.B.; Kuki, M.C.; Scapim, C.A. SNP-and haplotype-based GWAS of flowering-related traits in maize with network-assisted gene prioritization. Agronomy 2019, 9, 725. [CrossRef]

16. Nagamine, Y.; Pong-Wong, R.; Navarro, P.; Vitart, V.; Hayward, C.; Rudan, I.; Campbell, H.; Wilson, J.; Wild, S.; Hicks, A.A.; et al. Localising Loci underlying Complex Trait Variation Using Regional Genomic Relationship Mapping. PLoS ONE 2012, 7, e46501. [CrossRef] [PubMed]

17. Uemoto, Y.; Pong-Wong, R.; Navarro, P.; Vitart, V.; Hayward, C.; Wilson, J.F.; Rudan, I.; Campbell, H.; Hastie, N.D.; Wright, A.F.; et al. The power of regional heritability analysis for rare and common variant detection: Simulations and application to eye biometrical traits. Front. Genet. 2013, 4, 232. [CrossRef]

18. Resende, R.T.; Resende, M.D.V.; Silva, F.F.; Azevedo, C.F.; Takahashi, E.K.; Silva-Junior, O.B.; Grattapaglia, D. Regional heritability mapping and genome-wide association identify loci for complex growth, wood and disease resistance traits in Eucalyptus. New Phytol. 2017, 213, 1287-1300. [CrossRef] [PubMed] 
19. Haiman, C.A.; Patterson, N.; Freedman, M.L.; Myers, S.R.; Pike, M.C.; Waliszewska, A.; Neubauer, J.; Tandon, A.; Schirmer, C.; McDonald, G.J.; et al. Multiple regions within 8q24 independently affect risk for prostate cancer. Nat. Genet. 2007, 39, 638-644. [CrossRef]

20. Duerr, R.H.; Taylor, K.D.; Brant, S.R.; Rioux, J.D.; Silverberg, M.S.; Daly, M.J.; Steinhart, A.H.; Abraham, C.; Regueiro, M.; Griffiths, A.; et al. A Genome-Wide Association Study Identifies IL23R as an Inflammatory Bowel Disease Gene. Science 2006, 314, 1461-1463. [CrossRef]

21. Resende, R.T. Regional Heritability Mapping and Gwas for Molecular Breeding in Eucalyptus Hybrids. Ph.D. Thesis, Universidade Federal de Viçosa, Viçosa, MG, Brazil, 2017.

22. Shirali, M.; Pong-Wong, R.; Navarro, P.; Knott, S.; Hayward, C.; Vitart, V.; Rudan, I.; Campbell, H.; Hastie, N.D.; Wright, A.F.; et al. Regional heritability mapping method helps explain missing heritability of blood lipid traits in isolated populations. Heredity 2016, 116, 333-338. [CrossRef] [PubMed]

23. Caballero, A.; Tenesa, A.; Keightley, P.D. The Nature of Genetic Variation for Complex Traits Revealed by GWAS and Regional Heritability Mapping Analyses. Genetics 2015, 201, 1601-1613. [CrossRef]

24. Resende, R.T.; de Resende, M.D.V.; Azevedo, C.F.; Fonseca e Silva, F.; Melo, L.C.; Pereira, H.S.; Souza, T.L.P.O.; Valdisser, P.A.M.R.; Brondani, C.; Vianello, R.P. Genome-Wide Association and Regional Heritability Mapping of Plant Architecture, Lodging and Productivity in Phaseolus vulgaris. G3-Genes Genom. Genet. 2018, 8, 2841-2854. [CrossRef] [PubMed]

25. Okeke, U.G.; Akdemir, D.; Rabbi, I.; Kulakow, P.; Jannink, J. Regional Heritability Mapping Provides Insights into Dry Matter Content in African White and Yellow Cassava Populations. Plant Genome US 2018, 11, 1-18. [CrossRef] [PubMed]

26. Neves, L.G.; Davis, J.M.; Barbazuk, W.B.; Kirst, M. A High-Density Gene Map of Loblolly Pine (Pinus taeda L.) Based on Exome Sequence Capture Genotyping. G3 Genes Genomes Genet. 2014, 4, 29-37. [CrossRef] [PubMed]

27. Schwantes, I.A.; do Amaral Júnior, A.T.; Almeida Filho, J.E.; Vivas, M.; Silva Cabral, P.D.; Gonçalves Guimarães, A.; Lima e Silva, F.H.; Araújo Diniz Santos, P.H.; Gonzaga Pereira, M.; Pio Viana, A.; et al. Genomic selection helps accelerate popcorn population breeding. Crop Sci. 2020, 60, 1373-1385. [CrossRef]

28. Rigas, S.; Daras, G.; Tsitsekian, D.; Alatzas, A.; Hatzopoulos, P. Evolution and significance of the Lon gene family in Arabidopsis organelle biogenesis and energy metabolism. Front. Plant Sci. 2014, 5, 145. [CrossRef]

29. Zhang, M.; Wang, C.; Lin, Q.; Liu, A.; Wang, T.; Feng, X.; Liu, J.; Han, H.; Ma, Y.; Bonea, D.; et al. A tetratricopeptide repeat domain-containing protein SSR1 located in mitochondria is involved in root development and auxin polar transport in Arabidopsis. Plant J. 2015, 83, 582-599. [CrossRef]

30. Masuda, S.; Mizusawa, K.; Narisawa, T.; Tozawa, Y.; Ohta, H.; Takamiya, K. The Bacterial Stringent Response, Conserved in Chloroplasts, Controls Plant Fertilization. Plant Cell Physiol. 2008, 49, 135-141. [CrossRef]

31. Sun, R.; Ye, R.; Gao, L.; Zhang, L.; Wang, R.; Mao, T.; Zheng, Y.; Li, D.; Lin, Y. Characterization and Ectopic Expression of CoWRI1, an AP2/EREBP Domain-Containing Transcription Factor from Coconut (Cocos nucifera L.) Endosperm, Changes the Seeds Oil Content in Transgenic Arabidopsis thaliana and Rice (Oryza sativa L.). Front. Plant Sci. 2017, 8, 63. [CrossRef] [PubMed]

32. Arthikala, M.-K.; Quinto, C. RbohA coordinates lateral root emergence in common bean. Commun. Integr. Biol. 2018, 11, 1-5. [CrossRef] [PubMed]

33. Yoshioka, H.; Numata, N.; Nakajima, K.; Katou, S.; Kawakita, K.; Rowland, O.; Jones, J.D.G.; Doke, N. Nicotiana benthamiana gp91 phox Homologs NbrbohA and NbrbohB Participate in H2O2 Accumulation and Resistance to Phytophthora infestans. Plant Cell 2003, 15, 706-718. [CrossRef]

34. Chai, W.; Jiang, P.; Huang, G.; Jiang, H.; Li, X. Identification and expression profiling analysis of TCP family genes involved in growth and development in maize. Physiol. Mol. Biol. Plants 2017, 23, 779-791. [CrossRef] [PubMed]

35. Manohar, M.; Choi, H.W.; Manosalva, P.; Austin, C.A.; Peters, J.E.; Klessig, D.F. Plant and Human MORC Proteins Have DNA-Modifying Activities Similar to Type II Topoisomerases, but Require One or More Additional Factors for Full Activity. Mol. Plant-Microbe Interact. 2017, 30, 87-100. [CrossRef] [PubMed]

36. Nziengui, H.; Schoefs, B. Functions of reticulons in plants: What we can learn from animals and yeasts. Cell. Mol. Life Sci. 2009, 66, 584-595. [CrossRef]

37. Tai, F.J.; Yuan, Z.L.; Wu, X.L.; Zhao, P.F.; Hu, X.L.; Wang, W. Identification of membrane proteins in maize leaves, altered in expression under drought stress through polyethylene glycol treatment. Plant Omi. J. 2011, 4, 250-256.

38. Delgado-Alvarado, A.; Walker, R.P.; Leegood, R.C. Phosphoenolpyruvate carboxykinase in developing pea seeds is associated with tissues involved in solute transport and is nitrogen-responsive. Plant. Cell Environ. 2007, 30, 225-235. [CrossRef] [PubMed]

39. Avisar, D.; Abu-Abied, M.; Belausov, E.; Sadot, E.; Hawes, C.; Sparkes, I.A. A Comparative Study of the Involvement of 17 Arabidopsis Myosin Family Members on the Motility of Golgi and Other Organelles. Plant Physiol. 2009, 150, 700-709. [CrossRef]

40. Ge, W.; Song, Y.; Zhang, C.; Zhang, Y.; Burlingame, A.L.; Guo, Y. Proteomic analyses of apoplastic proteins from germinating Arabidopsis thaliana pollen. Biochim. Biophys. Acta Proteins Proteom. 2011, 1814, 1964-1973. [CrossRef]

41. Donnini, S.; Prinsi, B.; Negri, A.S.; Vigani, G.; Espen, L.; Zocchi, G. Proteomic characterization of iron deficiency responses in Cucumis sativus L. roots. BMC Plant Biol. 2010, 10, 268. [CrossRef]

42. Kong, F.; Deng, Y.; Zhou, B.; Wang, G.; Wang, Y.; Meng, Q. A chloroplast-targeted DnaJ protein contributes to maintenance of photosystem II under chilling stress. J. Exp. Bot. 2014, 65, 143-158. [CrossRef]

43. Yu, R.M.; Zhou, Y.; Xu, Z.F.; Chye, M.L.; Kong, R.Y. Two genes encoding protein phosphatase 2A catalytic subunits are differentially expressed in rice. Plant Mol. Biol. 2003, 51, 295-311. [PubMed] 
44. Dutt, S.; Parkash, J.; Mehra, R.; Sharma, N.; Singh, B.; Raigond, P.; Joshi, A.; Chopra, S.; Singh, B.P. Translation initiation in plants: Roles and implications beyond protein synthesis. Biol. Plant. 2015, 59, 401-412. [CrossRef]

45. País, S.M.; Téllez-Iñón, M.T.; Capiati, D.A. Serine/Threonine Protein Phosphatases type 2A and their roles in stress signaling. Plant Signal. Behav. 2009, 4, 1013-1015. [CrossRef] [PubMed]

46. Jue, D.; Sang, X.; Lu, S.; Dong, C.; Zhao, Q.; Chen, H.; Jia, L. Genome-Wide Identification, Phylogenetic and Expression Analyses of the Ubiquitin-Conjugating Enzyme Gene Family in Maize. PLoS ONE 2015, 10, e0143488. [CrossRef] [PubMed]

47. Bolduc, N.; Yilmaz, A.; Mejia-Guerra, M.K.; Morohashi, K.; O'Connor, D.; Grotewold, E.; Hake, S. Unraveling the KNOTTED1 regulatory network in maize meristems. Genes Dev. 2012, 26, 1685-1690. [CrossRef] [PubMed]

48. Capovilla, G.; Pajoro, A.; Immink, R.G.; Schmid, M. Role of alternative pre-mRNA splicing in temperature signaling. Curr. Opin. Plant Biol. 2015, 27, 97-103. [CrossRef] [PubMed]

49. Kim, M.; Hersh, L.B.; Leissring, M.A.; Ingelsson, M.; Matsui, T.; Farris, W.; Lu, A.; Hyman, B.T.; Selkoe, D.J.; Bertram, L.; et al. Decreased Catalytic Activity of the Insulin-degrading Enzyme in Chromosome 10-Linked Alzheimer Disease Families. J. Biol. Chem. 2007, 282, 7825-7832. [CrossRef]

50. Kuramata, M.; Masuya, S.; Takahashi, Y.; Kitagawa, E.; Inoue, C.; Ishikawa, S.; Youssefian, S.; Kusano, T. Novel Cysteine-Rich Peptides from Digitaria ciliaris and Oryza sativa Enhance Tolerance to Cadmium by Limiting its Cellular Accumulation. Plant Cell Physiol. 2009, 50, 106-117. [CrossRef] [PubMed]

51. Li, Y.; Kabbage, M.; Liu, W.; Dickman, M.B. Aspartyl Protease-Mediated Cleavage of BAG6 Is Necessary for Autophagy and Fungal Resistance in Plants. Plant Cell 2016, 28, 233-247. [CrossRef]

52. Ostertag, M.; Stammler, J.; Douchkov, D.; Eichmann, R.; Hückelhoven, R. The conserved oligomeric Golgi complex is involved in penetration resistance of barley to the barley powdery mildew fungus. Mol. Plant Pathol. 2013, 14, 230-240. [CrossRef]

53. Zhang, L.; Tian, L.-H.; Zhao, J.-F.; Song, Y.; Zhang, C.-J.; Guo, Y. Identification of an Apoplastic Protein Involved in the Initial Phase of Salt Stress Response in Rice Root by Two-Dimensional Electrophoresis. Plant Physiol. 2009, 149, 916-928. [CrossRef]

54. Stirpe, F. Ribosome-inactivating proteins: From toxins to useful proteins. Toxicon 2013, 67, 12-16. [CrossRef]

55. Tian, S.; Muneeruddin, K.; Choi, M.Y.; Tao, L.; Bhuiyan, R.H.; Ohmi, Y.; Furukawa, K.; Furukawa, K.; Boland, S.; Shaffer, S.A.; et al. Genome-wide CRISPR screens for Shiga toxins and ricin reveal Golgi proteins critical for glycosylation. PLoS Biol. 2018, 16, e2006951. [CrossRef] [PubMed]

56. Walley, J.W.; Kelley, D.R.; Nestorova, G.; Hirschberg, D.L.; Dehesh, K. Arabidopsis Deadenylases AtCAF1a and AtCAF1b Play Overlapping and Distinct Roles in Mediating Environmental Stress Responses. Plant Physiol. 2010, 152, 866-875. [CrossRef] [PubMed]

57. Hsu, K.; Liu, C.; Wu, S.; Kuo, Y.; Lu, C.; Wu, C.; Lian, P.; Hong, C.; Ke, Y.; Huang, J.; et al. Expression of a gene encoding a rice RING zinc-finger protein, OsRZFP34, enhances stomata opening. Plant Mol. Biol. 2014, 86, 125-137. [CrossRef]

58. Jia, F.; Wan, X.; Zhu, W.; Sun, D.; Zheng, C.; Liu, P.; Huang, J. Overexpression of Mitochondrial Phosphate Transporter 3 Severely Hampers Plant Development through Regulating Mitochondrial Function in Arabidopsis. PLoS ONE 2015, 10, e0129717. [CrossRef]

59. Jamann, T.M.; Luo, X.; Morales, L.; Kolkman, J.M.; Chung, C.L.; Nelson, R.J. A remorin gene is implicated in quantitative disease resistance in maize. Theor. Appl. Genet. 2016, 129, 591-602. [CrossRef]

60. Iglesias-Fernández, R.; Rodríguez-Gacio, M.C.; Barrero-Sicilia, C.; Carbonero, P.; Matilla, A. Three endo- $\beta$-mannanase genes expressed in the micropylar endosperm and in the radicle influence germination of Arabidopsis thaliana seeds. Planta 2011, 233, 25-36. [CrossRef]

61. Qi, Y.; Liu, Y.; Zhang, Z.; Gao, J.; Guan, Z.; Fang, W.; Chen, S.; Chen, F.; Jiang, J. The over-expression of a chrysanthemum gene encoding an RNA polymerase II CTD phosphatase-like 1 enzyme enhances tolerance to heat stress. Hortic. Res. $2018,5,37$. [CrossRef]

62. Newell, M.A.; Cook, D.; Tinker, N.A.; Jannink, J.-L. Population structure and linkage disequilibrium in oat (Avena sativa L.): Implications for genome-wide association studies. Theor. Appl. Genet. 2011, 122, 623-632. [CrossRef] [PubMed]

63. Morosini, J.S.; de Freitas Mendonça, L.; Lyra, D.H.; Galli, G.; Vidotti, M.S.; Fritsche-Neto, R. Association mapping for traits related to nitrogen use efficiency in tropical maize lines under field conditions. Plant Soil 2017, 421, 453-463. [CrossRef]

64. Wang, M.; Yan, J.; Zhao, J.; Song, W.; Zhang, X.; Xiao, Y.; Zheng, Y. Genome-wide association study (GWAS) of resistance to head smut in maize. Plant Sci. 2012, 196, 125-131. [CrossRef]

65. Viana, J.M.S.; e Silva, F.F.; Mundim, G.B.; Azevedo, C.F.; Jan, H.U. Efficiency of low heritability QTL mapping under high SNP density. Euphytica 2017, 213, 13. [CrossRef]

66. Arnhold, E.; Mora, F.; Silva, R.G.; Good-God, P., IV; Rodovalho, M.A. Evaluation of top-cross popcorn hybrids using Mixed Linear Model methodology. Chil. J. Agric. Res. 2009, 69, 46-53. [CrossRef]

67. Soni, N.V.; Khanorkar, S.M. Genetic architecture of yield traits and popping quality in popcorn (Zea mays var. everta) inbred lines. Electron. J. Plant Breed. 2014, 5, 11-16.

68. de Rodovalho, M.A.; Mora, F.; dos Santos, E.M.; Scapim, C.A.; Arnhold, E. Heredabilidad de la sobrevivencia en 169 familias de maíz-roseta de granos blancos: Un enfoque Bayesiano. Int. J. Agric. Nat. Resour. 2008, 35, 303-309. [CrossRef]

69. Ribeiro, R.M.; do Amaral Júnior, A.T.; Gonçalves, L.S.A.; Candido, L.S.; Silva, T.R.C.; Pena, G.F. Genetic progress in the UNB-2U population of popcorn under recurrent selection in Rio de Janeiro, Brazil. Genet. Mol. Res. 2012, 11, 1417-1423. [CrossRef] 
70. Ribeiro, R.M.; do Amaral Júnior, A.T.; Pena, G.F.; Vivas, M.; Kurosawa, R.N.; Gonçalves, L.S.A. Effect of recurrent selection on the variability of the UENF-14 popcorn population. Crop Breed. Appl. Biotechnol. 2016, 16, 123-131. [CrossRef]

71. Guimarães, A.G.; do Amaral Júnior, A.T.; Pena, G.F.; de Almeida filho, J.E.; Pereira, M.G.; Santos, P.H.A.D. Genetic gains in the popcorn population UENF-14: Developing the ninth generation of intrapopulation recurrent selection. Rev. Caatinga 2019, 32, 625-633. [CrossRef]

72. Yu, Y.; Zhao, Z.; Shi, Y.; Tian, H.; Liu, L.; Bian, X.; Xu, Y.; Zheng, X.; Gan, L.; Shen, Y.; et al. Hybrid Sterility in Rice (Oryza sativa L.) Involves the Tetratricopeptide Repeat Domain Containing Protein. Genetics 2016, 203, 1439-1451. [CrossRef] [PubMed]

73. Sharma, M.; Pandey, G.K. Expansion and Function of Repeat Domain Proteins During Stress and Development in Plants. Front. Plant Sci. 2016, 6, 1218. [CrossRef] [PubMed]

74. Awasthi, A.; Paul, P.; Kumar, S.; Verma, S.K.; Prasad, R.; Dhaliwal, H.S. Abnormal endosperm development causes female sterility in rice insertional mutant OsAPC6. Plant Sci. 2012, 183, 167-174. [CrossRef]

75. Wu, Y.; Pu, C.; Lin, H.; Huang, H.; Huang, Y.; Hong, C.; Chang, M.; Lin, Y. Three novel alleles of FLOURY ENDOSPERM2 (FLO2 ) confer dull grains with low amylose content in rice. Plant Sci. 2015, 233, 44-52. [CrossRef] [PubMed]

76. She, K.-C.; Kusano, H.; Koizumi, K.; Yamakawa, H.; Hakata, M.; Imamura, T.; Fukuda, M.; Naito, N.; Tsurumaki, Y.; Yaeshima, M.; et al. A Novel Factor FLOURY ENDOSPERM2 Is Involved in Regulation of Rice Grain Size and Starch Quality. Plant Cell 2010, 22, 3280-3294. [CrossRef]

77. Liu, C.; Zhang, T. Expansion and stress responses of the AP2/EREBP superfamily in cotton. BMC Genom. 2017, 18, 118. [CrossRef]

78. Zhang, M.; Chen, Y.; Jin, X.; Cai, Y.; Yuan, Y.; Fu, C.; Yu, L. New different origins and evolutionary processes of AP2/EREBP transcription factors in Taxus chinensis. BMC Plant Biol. 2019, 19, 413. [CrossRef]

79. Khan, M.B.; Hussain, N.; Iqbal, M. Effect of water stress on growth and yield components of maize variety YHS 202. J. Res. 2001, $12,15-18$.

80. Borrmann, D.; de Junqueira, R.M.; Sinnecker, P.; de Gomes, M.S.O.; Castro, I.A.; Marquez, U.M.L. Chemical and biochemical characterization of soybean produced under drought stress. Ciência Tecnol. Aliment. 2009, 29, 676-681. [CrossRef]

81. Terra, T.G.R.; de Leal, T.C.A.B.; Borém, A.; Rangel, P.H.N. Tolerância de linhagens de arroz de terras altas à seca. Pesqui. Agropecuária Trop. 2013, 43, 201-208. [CrossRef]

82. Zain, N.A.M.; Ismail, M.R.; Puteh, A.; Mahmood, M.; Islam, M.R. Impact of cyclic water stress on growth, physiological responses and yield of rice (Oryza sativa L.) grown in tropical environment. Ciência Rural 2014, 44, 2136-2141. [CrossRef]

83. Kamphorst, S.H.; Lima, V.J.; Schimitt, K.F.M.; Leite, J.T.; Azeredo, V.C.; Pena, G.F.; Santos, P.H.A.D.; Júnior, D.R.S.; da Júnior, S.B.S.; Bispo, R.B.; et al. Water stress adaptation of popcorn roots and association with agronomic traits. Genet. Mol. Res. 2018, 17, 1-14. [CrossRef]

84. Zheng, K.; Ni, Z.; Qu, Y.; Cai, Y.; Yang, Z.; Sun, G.; Chen, Q. Genome-wide identification and expression analyses of TCP transcription factor genes in Gossypium barbadense. Sci. Rep. 2018, 8, 14526. [CrossRef] [PubMed]

85. Koyama, T.; Furutani, M.; Tasaka, M.; Ohme-Takagi, M. TCP Transcription Factors Control the Morphology of Shoot Lateral Organs via Negative Regulation of the Expression of Boundary-Specific Genes in Arabidopsis. Plant Cell 2007, 19, 473-484. [CrossRef] [PubMed]

86. Parapunova, V.; Busscher, M.; Busscher-Lange, J.; Lammers, M.; Karlova, R.; Bovy, A.G.; Angenent, G.C.; de Maagd, R.A. Identification, cloning and characterization of the tomato TCP transcription factor family. BMC Plant Biol. 2014, $14,157$. [CrossRef] [PubMed]

87. Koteyeva, N.K.; Voznesenskaya, E.V.; Edwards, G.E. An assessment of the capacity for phosphoenolpyruvate carboxykinase to contribute to C4 photosynthesis. Plant Sci. 2015, 235, 70-80. [CrossRef]

88. Qin, N.; Xu, W.; Hu, L.; Li, Y.; Wang, H.; Qi, X.; Fang, Y.; Hua, X. Drought tolerance and proteomics studies of transgenic wheat containing the maize C4 phosphoenolpyruvate carboxylase (PEPC) gene. Protoplasma 2016, 253, 1503-1512. [CrossRef]

89. Hu, L.; Li, Y.; Xu, W.; Zhang, Q.; Zhang, L.; Qi, X.; Dong, H. Improvement of the photosynthetic characteristics of transgenic wheat plants by transformation with the maize C4 phosphoenolpyruvate carboxylase gene. Plant Breed. 2012, 131, 385-391. [CrossRef]

90. Leegood, R.C.; Walker, R.P. Regulation and roles of phosphoenolpyruvate carboxykinase in plants. Arch. Biochem. Biophys. 2003, 414, 204-210. [CrossRef]

91. Xu, M.; Li, L.; Fan, Y.; Wan, J.; Wang, L. ZmCBF3 overexpression improves tolerance to abiotic stress in transgenic rice (Oryza sativa) without yield penalty. Plant Cell Rep. 2011, 30, 1949-1957. [CrossRef]

92. Xu, Y.; Yu, Z.; Zhang, D.; Huang, J.; Wu, C.; Yang, G.; Yan, K.; Zhang, S.; Zheng, C. CYSTM, a Novel Non-Secreted Cysteine-Rich Peptide Family, Involved in Environmental Stresses in Arabidopsis thaliana. Plant Cell Physiol. 2018, 59, 423-438. [CrossRef]

93. Zhu, W.; Miao, Q.; Sun, D.; Yang, G.; Wu, C.; Huang, J.; Zheng, C. The Mitochondrial Phosphate Transporters Modulate Plant Responses to Salt Stress via Affecting ATP and Gibberellin Metabolism in Arabidopsis thaliana. PLoS ONE 2012, 7, e43530. [CrossRef]

94. Climate Data for Cities Worldwide-Climate-Data.org. OpenStreetMap Contributor. Available online: https:/ / en.climate-data. org/amerika-selatan/brasil/rio-de-janeiro-208/ (accessed on 11 August 2021).

95. Fontes, P.S.F.; Carvalho, A.J.C.D.; Cereja, B.S.; Marinho, C.S.; Monnerat, P.H. Avaliação do estado nutricional e do desenvolvimento da bananeira-prata-anã (Musa spp.) em função da adubação nitrogenada. Rev. Bras. Frutic. 2003, 25, 156-159. [CrossRef] 
96. Amaral Júnior, A.T.; Gonçalves, L.S.A.; de Freitas Júnior, S.P.; Candido, L.S.; Vittorazzi, C.; Pena, G.F.; Ribeiro, R.M.; da Silva, T.R.C.; Pereira, M.G.; Scapim, C.A.; et al. UENF 14: A new popcorn cultivar. Crop Breed. Appl. Biotechnol. 2013, 13, 218-220. [CrossRef]

97. Daros, M.; do Amaral Júnior, A.T.; Pereira, M.G. Genetic gain for grain yield and popping expansion in full-sib recurrent selection in popcorn. Crop Breed. Appl. Biot. 2002, 2, 339-344. [CrossRef]

98. Daros, M.; Amaral, A.T.D., Jr.; Pereira, M.G.; Santos, F.S.; Gabriel, A.P.C.; Scapim, C.A.; Freitas Júnior, S.D.P.; Silvério, L. Recurrent selection in inbred popcorn families. Sci. Agr. 2004, 61, 609-614. [CrossRef]

99. Santos, F.S.; Amaral Júnior, A.T.D.; Freitas Júnior, S.D.P.; Rangel, R.M.; Pereira, M.G. Predição de ganhos genéticos por índices de seleção na população de milho pipoca UNB-2U sob seleção recorrente. Bragantia 2007, 66, 389-396. [CrossRef]

100. Freitas, S.P., Jr.; Amaral Juniot, A.T.; Rangel, R.M.; Viana, A.P. Genetic gains in popcorn by full-sib recurrent selection. Crop. Breed. Appl. Biotechnol. 2009, 9, 1-7. [CrossRef]

101. Rangel, R.M.; doAmaral Júnior, T.; Gonçalves, L.S.; Freitas Júnior, S.D.; Candido, L.S. Biometric analysis of selection gains in popcorn population of the fifth cycle of recurrent selection. Rev. Cienc. Agron. 2011, 42, 473. [CrossRef]

102. Freitas, I.L.J.; Amaral Júnior, A.T.; Freitas Júnior, S.P.; Cabral, P.D.S.; Ribeiro, R.M.; Goncalves, L.S.A. Genetic gains in the UENF-14 popcorn population with recurrent selection. Genet. Mol. Res. 2014, 13, 518-527. [CrossRef] [PubMed]

103. Bates, D.; Mächler, M.; Bolker, B.; Walker, S. Fitting Linear Mixed-Effects Models Using lme4. J. Stat. Softw. 2015, 67, 1-51. [CrossRef]

104. R Core Team, R. A Language and Environment for Statistical Computing; R Core Team R: Vienna, Austria, 2016.

105. Lenth, R.V. Least-Squares Means: The R Package lsmeans. J. Stat. Softw. 2016, 69, 1-33. [CrossRef]

106. Doyle, J.J.; Doyle, J.L. Isolation of plant DNA from fresh tissue. Focus 1990, 12, 13-15.

107. Endelman, J.B. Ridge Regression and Other Kernels for Genomic Selection with R Package rrBLUP. Plant Genome J. 2011, 4, 250. [CrossRef]

108. VanRaden, P.M. Efficient Methods to Compute Genomic Predictions. J. Dairy Sci. 2008, 91, 4414-4423. [CrossRef]

109. Purcell, S.; Neale, B.; Todd-Brown, K.; Thomas, L.; Ferreira, M.A.R.; Bender, D.; Maller, J.; Sklar, P.; de Bakker, P.I.W.; Daly, M.J.; et al. PLINK: A Tool Set for Whole-Genome Association and Population-Based Linkage Analyses. Am. J. Hum. Genet. 2007, 81, 559-575. [CrossRef] [PubMed]

110. Hill, W.G.; Weir, B.S. Variances and covariances of squared linkage disequilibria in finite populations. Theor. Popul. Biol. 1988, 33, 54-78. [CrossRef]

111. Clifford, D.; McCullagh, P. The Regress Package; R Package Version; R Core Team R: Vienna, Austria, 2012; pp. 1-3.

112. Schnable, P.S.; Ware, D.; Fulton, R.S.; Stein, J.C.; Wei, F.; Pasternak, S.; Liang, C.; Zhang, J.; Fulton, L.; Graves, T.A.; et al. The B73 Maize Genome: Complexity, Diversity, and Dynamics. Science 2009, 326, 1112-1115. [CrossRef] 